ISSN: 2224-0616

Int. J . Agril. Res. Innov. \& Tech. 4 (2): 22-28, December, 2014 Available online at http://www.ijarit.webs.com

\title{
STATUS OF COMPOST USAGE AND ITS PERFORMANCE ON VEGETABLE PRODUCTION IN MONGA AREAS OF BANGLADESH
}

\author{
G.K.M.M. Rahman', M.S.I. Afrad ${ }^{2 *}$ and M.M. Rahman ${ }^{3}$
}

Received 4 July 2014, Revised 26 October 2014, Accepted 22 December 2014, Published online 31 December 2014

\begin{abstract}
The present study was carried out to assess the existing status of compost usage on vegetable production and determine the overall effect of household waste compost (HWC) on growth and yield of vegetables and enhancement of soil fertility in the monga areas of Bangladesh. A field survey was conducted on 152 sampled farmers during 2010 to 2011. Questionnaire containing both closed and open-ended questions were used to assess existing production practices of vegetables using compost in both homestead and field conditions. Three field trials at Badargonj and Kawnia upazilas of Rangpur district were conducted taking four treatments i.e. control, recommended doses (RD) of fertilizers, HWC at the rate of 10 tha $^{-1}$, and HWC 10 t ha-1 $^{-1}$ plus RD as IPNS based with Lal shak, Palong shak, Pui shak and Tomato. Base line survey results indicated inadequate knowledge of the farmers on use and preparation of the household waste compost. Yield data of all vegetables i.e. Tomato, Lal shak, Palong shak and Pui shak indicated that the combined application of nutrients using organic and inorganic sources were significantly better than that of solitary application of inorganic fertilizers. The potential of household waste compost applied @ $10 \mathrm{t} \mathrm{ha}^{-1}$ along with inorganic fertilizers applied was found highly satisfactory in producing Tomato, where yield was recorded $75 \mathrm{t} \mathrm{ha}^{-1}$ in the study area. The fresh yield of Palong shak was found $16 \mathrm{t}$ ha- ${ }^{-1}$ when recommended doses of inorganic fertilizers were applied, but it was about $19 \mathrm{t} \mathrm{ha}^{-1}$ under combined application of HWC @ $10 \mathrm{t} \mathrm{ha}^{-1}$ and inorganic fertilizers following IPNS concept. The fresh yield of Pui shak was found about $49 \mathrm{t} \mathrm{ha}^{-1}$ under combined application of organic and inorganic nutrients. Considering the availability and costs of different composts, it is evinced that HWC contained good amount of NPK which indicates its potentiality to be used as a soil amendment, improving soil fertility and crop productivity. It can be an alternative to chemical fertilizer to increase soil microbial populations and enzyme activities and to promote the soil nutrient for horticultural crops in the unfertile areas especially in the monga areas of Bangladesh.
\end{abstract}

Keywords: Compost, Monga, Vegetable, Soil Fertility

${ }^{1 \& 3}$ Department of Soil Science, Bangabandhu Sheikh Mujibur Rahman Agricultural University, Salna, Gazipur, Bangladesh ${ }^{2}$ Department of Agricultural Extension and Rural Development, Bangabandhu Sheikh Mujibur Rahman Agricultural University, Salna, Gazipur, Bangladesh

*Corresponding author's email: afrad69@gmail.com (M.S.I. Afrad)

\section{Introduction}

It is a great challenge to keep the agricultural production system sustainable under changing climate. Agriculture in Bangladesh faces the challenge of producing crops from its limited land resource to meet up the huge demand of foods for its ever-growing population. The scope is limited to bring new land under cultivation. Therefore, intensification of land with modern crop varieties for increased production is a necessary (Rahman and Azam, 2005). Heavy pressure on agricultural land through intensive cultivation of high yielding crop varieties using inorganic fertilizers solely and almost no recycling from organic residues has led to decline organic matter and mining out the inherent plant nutrients from soils (Karim et al., 1994). Soil organic matter is an indicator of its fertility and thereby crop productivity. According to BARC (2005), a good soil should have at least $2.5 \%$ organic matter, but most of the soils in Bangladesh have less than $1.5 \%$, and some soils even less than $1 \%$ organic matter. The soils of the Monga area of Bangladesh are seriously depleted and organic matter content is very low. Monga is a local term, which means seasonal food scarcity occurring in September - November and March April in the northern part of Bangladesh. During the period people become jobless leading to poverty. Production of short duration vegetables during this crisis period using household waste compost can be a better option for increasing income, available of domestic foodstuff towards reduction of monga. The use of household waste, 
poultry manure and cow dung contributes to the requirement to maintain the long-term fertility of soils by improving physical and chemical properties of soils (Rahman, 2010). Cow dung and crop residues are used as fuel for cooking in many rural areas of Bangladesh and thereby are not available for using in the crop fields. However, household waste is available in everywhere and its composting is very easy. Household waste contains valuable plant nutrients especially $\mathrm{N}, \mathrm{P}, \mathrm{S}, \mathrm{K}$ and many other macro and micronutrients, which may pollute the environment if not properly managed and utilized for crop production. Agricultural use of household waste may substantially cut down the cost of production reducing application of inorganic fertilizers especially for short duration vegetable production in the homestead and thus ensure an eco-friendly environment. Therefore, household waste compost could be a good alternative for replenishment of organic matter in soils. Therefore, the project was designed to (a) assess the existing status of using organic manures in vegetable production, (b) motivate the farmers for preparing household wastes compost for vegetable production, and (c) improve soil health in the project area.

\section{Methodologies}

\section{Social survey}

Interview schedule containing both closed and open-ended questions were prepared as per project objectives. A total of 152-farmers (68 from Kawnia and 84 from Badarganj upazilas of Rangpur district of Bangladesh) were selected based on some criteria viz., home near to wellcommunicated road; possess at least two decimal spare and sunny homestead area and willing to cultivate vegetables following guidelines provided by the project authority. Trained enumerators were engaged to collect primary data from the selected respondents. The field survey was conducted to delve into their livelihood activities including vegetables production practices, income and expenditure, education and health care, and other related aspects of food quality and production. Selected respondents were trained on preparation of household waste compost and its application for vegetable production in homestead areas. Of them twenty were chosen for conducting trial. As per project objectives, selected farmers prepared household wastes compost in their own homestead and used for vegetable production in the same areas.

\section{Field trials}

A series of trials were laid out in a factorial (nutrients $\mathrm{x}$ locations) randomized complete block design with four replications during 20102011. The four levels of nutrient treatments were: (1) control, (2) recommended doses (RD) of fertilizers, (3) household waste compost (HWC) at the rate of 10 t ha- $^{-1}$, and (4) HWC 10 t ha$^{-1}$ plus $\mathrm{RD}$ as IPNS based. During the 2010-11 two trials (first one as per nutrient treatments mentioned and the second one using residual nutrients i.e. without applying either compost or inorganic fertilizers) with Palong shak (Spinach) were conducted in 17 locations/villages (Kawnia 7 and Badarganj 10). The dates of sowing of Palong shak seeds were November 3 to December 14, 2010 for the first trial, while for the second one were December 11, 2010 to January 20, 2011. The crop was harvested after 30-35 days of sowing. During the 2010-11, among 17 villages ten were selected (Kawnia 5 and Badarganj 5) to grow Lal shak (Red Amaranth) as first crop using nutrients as per treatments, while second crop Pui shak (Indian spinach) without applying nutrients. The seeds of Lal shak was sown on February 10, 2011 and harvested on March 18, 2011. The Pui shak was sown on April 10, 2011 and harvested on June 8, 2011. During 2010-11, one farmer from Kawnia grew Lal shak, Pui shak and Tomato as first, second and third crops, respectively in the same piece of land using above mentioned four treatments. The Lal shak was sown on July 1, 2010 and harvested on August 4, 2010, while Pui shak was sown on August 19, 2010 and harvested on September 25, 2010. Tomato seedlings were transplanted on November 23, 2010 and final harvest was done on March 25, 2011. In the treatment 4, where household waste compost was applied at the rate of $10 \mathrm{t} \mathrm{ha}^{-1}$ plus recommended doses of N, P and K as IPNS based before sowing Lal shak and after that Pui shak was grown without applying nutrients and Tomato was grown using only nitrogen $(\mathrm{N})$ at the rate of $117 \mathrm{~kg}$ ha $^{-1}$. Before applying to soils house hold waste compost, and initial soil were analyzed for quantifying the nutrients (Table 1) and then rates of chemical fertilizers were calculated following IPNS concept.

Table 1. N, P and K content of household waste compost and initial soil in the study area

\begin{tabular}{lccccc}
\hline Waste material & $\begin{array}{c}\text { Total N } \\
(\%)\end{array}$ & $\begin{array}{c}\text { Available N } \\
(\%)\end{array}$ & $\begin{array}{c}\text { Total P } \\
\left(\mathrm{mg} \mathrm{kg}^{1}\right)\end{array}$ & $\begin{array}{c}\text { AvailableP } \\
\left(\mathrm{mg} \mathrm{kg}^{1} \text { soil }\right)\end{array}$ & $\begin{array}{c}\text { Exchangeable K } \\
\left(\mathrm{mg} \mathrm{kg}^{1} \text { soil }\right)\end{array}$ \\
\hline Household waste compost & 1.36 & 0.089 & 1650 & 450 & 1410 \\
Plot soil & 0.090 & 0.030 & - & 12.84 & $0.14 *$ \\
\hline
\end{tabular}

* unit of $\mathrm{K}$ for plot soil was meq $100 \mathrm{~g}^{-1}$ soil that was for fertilizer recommendation of crops 
After harvesting of the Lal shak and Tomato soil samples were collected from each plot at $0-15 \mathrm{~cm}$ depth and were analyzed for $\mathrm{pH}, \mathrm{OM}$ and residual nutrients. Soil $\mathrm{pH}$ was determined by Glass Electrode $\mathrm{pH}$ Meter method with soil water ratio 1:2.5 (McLean, 1982), OM by Walkley-Black method (Nelson and Sommers, 1982), total N was determined by Kjeldhal systems (Bremner and Mulvaney, 1982), total $\mathrm{P}$ was determined by the Acid Digestion method (J ones and Case, 1990; Watson and Issac, 1990), available P by Olsen's method (Olsen and Sommers, 1982), and K by Ammonium acetate extraction method (Barker and Surh, 1982). Available $\mathrm{N}\left(\mathrm{NO}_{3}^{-}-\mathrm{N}\right.$ plus $\mathrm{NH}_{4}{ }^{+-}$ N) was determined using Steam Distillation method (Keeney and Nelson, 1982). The analyses of variance for different parameters were done following the principle of F-statistics and the mean results was compared using Duncan's Multiple Range Test (DMRT).

\section{Results and Discussion}

\section{Social survey}

Base line survey was conducted on selected 152 farmers (68 from Kawnia and 84 from Badargonj, Rangpur). The main emphasis of the base line survey was on the knowledge of the respondents on preparation and use of household wastes compost and benefits of cultivating vegetables. The findings obtained have been presented in the following headings:

Preparation of household wastes compost with cow dung

Village people usually do not prepare and use scientifically household wastes compost. Rural women throw these here and there around their homestead. Household wastes composts can be prepared in many ways. Information displayed in Table 2 indicate that about four-fifths of the respondents (79\%) are using cow dung compost including household wastes and interestingly about one-fifth (21\%) used it in other ways.

Table 2. Distribution of the respondents according to types of preparation of household wastes compost with cow dung

\begin{tabular}{lcc}
\hline Preparation of household & \multicolumn{2}{c}{ Respondents } \\
\cline { 2 - 3 } wastes compost with cow dung & Number & Per cent \\
\hline Direct application in the field & 0 & 0 \\
Compostingin separate pit & 0 & 0 \\
Composting with cow dung & 120 & 79 \\
Other ways (if any) & 32 & 21 \\
\hline
\end{tabular}

Time of preparation of cow dung compost

Findings available in Table 3 show that almost all of the respondents (91\%) are found using cow dung compost during final land preparation. Though the next negligible portion of them $(9 \%)$ are found using cow dung compost in other ways i.e. throw in the field whenever available, use during intercultural operations.
Table 3. Distribution of the respondents according to the time of preparation of cow dung compost

\begin{tabular}{lcc}
\hline Time of using cow dung & \multicolumn{2}{c}{ Respondents } \\
\cline { 2 - 3 } compost & Number & Per cent \\
\hline During final land preparation & 138 & 91 \\
After 15 days of planting & 0 & 0 \\
After 30 days of planting & 0 & 0 \\
Other ways (if any) & 14 & 20 \\
\hline
\end{tabular}

Doses of cow dung compost

Fertilizers and manures are applied in the field based on the demand of the crops grown. The respondents do not care for required doses of the cow dung compost. Information displayed in the Table 4 point out that more than half of the respondents (51\%) use cow dung compost @ $10 \mathrm{t}$ ha $^{-1}$ followed by near about half (45\%) use @10 t ha-1.

Table 4. Distribution of the respondents according to the using doses of cow dung compost

\begin{tabular}{lcc}
\hline \multirow{2}{*}{ Doses of cow dung compost } & \multicolumn{2}{c}{ Respondents } \\
\cline { 2 - 3 } & Number & Per cent \\
\hline 5 t ha $^{-1}$ & 6 & 4 \\
10 t ha $^{-1}$ & 77 & 51 \\
15 tha $^{-1}$ & 69 & 45 \\
20 t ha $^{-1}$ & 2 & 1 \\
\hline
\end{tabular}

Benefits of using household wastes compost

There are lot of benefits can be harvested by using cow dung compost like increased soil fertility, sound environment, low production cost, higher yield of vegetables, better quality of products etc. Respondents were asked for demonstrating their opinions regarding the benefits of using cow dung compost. Results demonstrated in Table 5 specify that more than four-fifths of the respondents (84\%) indicate low production cost, followed by 18 per cent higher yield of vegetables and 13 percent increased soil fertility as the benefits of using cow dung compost.

Table 5. Distribution of the respondents according to their responses on the benefits of using cow dung compost

\begin{tabular}{lcc}
\hline Benefits of using cow dung & \multicolumn{2}{c}{ Respondents } \\
\cline { 2 - 3 } compost & Number & Per cent \\
\hline Increase soil fertility & 19 & 13 \\
Low production cost & 128 & 84 \\
Higher yield of vegetables & 28 & 18 \\
Sound environment & 2 & 1 \\
Others & 0 & 0 \\
\hline
\end{tabular}

Usefulness of vegetables cultivation

Vegetable cultivation may harvest varieties of advantages like high nutritional value, short durational, prevent disease, higher income etc. However, almost all of the respondents (91\%) under study point out higher income as one of the most benefit of vegetable cultivation. A tiny portion of them (8\%) indicates prevention of diseases, followed by high nutritional value (5\%) and short duration (3\%) as the advantages of vegetable cultivation (Table 6). 
Table 6. Distribution of the respondents according to their knowledge on the usefulness of vegetables cultivation

\begin{tabular}{lcc}
\hline Benefits of cultivating & \multicolumn{2}{c}{ Respondents } \\
\cline { 2 - 3 } vegetables & Number & Percent \\
\hline High nutritional value & 8 & 5 \\
Short durational & 5 & 3 \\
Prevent disease & 12 & 8 \\
Higher income & 139 & 91 \\
Others & 0 & 0 \\
\hline
\end{tabular}

\section{Results of field trials in the study area}

Fresh yields of Palong shak

Fresh yields of Palong shak were significantly affected by different nutrient levels over the control (Table 7), but location did not show any significant effect on its yield (Table 8).

Table 7. Fresh yield of Palong shak under different nutrient levels in Kawnia and Badarganj, Rangpur

\begin{tabular}{|c|c|c|}
\hline \multirow{2}{*}{ Nutrient levels } & \multicolumn{2}{|c|}{$\begin{array}{c}\text { Fresh yield of } \\
\text { Palong shak }\left(\mathrm{t} \mathrm{ha}^{-1}\right)\end{array}$} \\
\hline & $\begin{array}{c}\text { First } \\
\text { harvest }\end{array}$ & $\begin{array}{l}\text { Second } \\
\text { harvest }\end{array}$ \\
\hline Control & $3.62 \mathrm{c}$ & $4.91 \mathrm{~b}$ \\
\hline Recommended doses of NPK & 15.79b & $16.09 a$ \\
\hline Household waste 10 t ha $^{-1}$ & $15.67 \mathrm{~b}$ & 17.99a \\
\hline $\begin{array}{l}\text { Household waste } 10 \mathrm{t} \mathrm{ha}^{-1}+ \\
\mathrm{RD}^{*} \text { of } \mathrm{N} \text { (IPNS concept) }\end{array}$ & 18.55a & $18.86 \mathrm{a}$ \\
\hline S.E. $( \pm)$ & 0.36 & 0.27 \\
\hline$\% \mathrm{CV}$ & 22.16 & 22.49 \\
\hline
\end{tabular}

$* \mathrm{RD}=$ Recommended dose

Table 8. Fresh yield of Palong shak under different locations in Kawnia and Badarganj, Rangpur

\begin{tabular}{llcc}
\hline \multirow{2}{*}{ Locations } & & \multicolumn{2}{c}{$\begin{array}{c}\text { Fresh yield of palong } \\
\text { shak }\left(\mathrm{t} \mathrm{ha}^{-1}\right)\end{array}$} \\
\hline Upazila & Village & $\begin{array}{c}\text { First } \\
\text { harvest }\end{array}$ & $\begin{array}{c}\text { Second } \\
\text { harvest }\end{array}$ \\
\hline Kawnia & Kachu & 10.86 & 11.17 \\
& Shingerkura & 13.21 & 10.53 \\
& Nazirdah & 13.14 & 14.46 \\
& Shabdi & 13.04 & 15.36 \\
& Madhupur & 13.99 & 14.30 \\
& Shahabaz & 13.24 & 16.56 \\
Badarganj & Haragach & 14.57 & 14.89 \\
& Shonkorpur & 13.31 & 17.63 \\
& Amrulbari & 12.84 & 13.11 \\
& Kachabari & 12.99 & 13.31 \\
& Nataram & 13.67 & 14.98 \\
& Rajarampur & 14.36 & 14.68 \\
& Gopalpur & 14.14 & 13.41 \\
& Khiarpara & 14.27 & 16.51 \\
& Radanagar & 14.11 & 12.42 \\
& Osmanpur & 13.62 & 15.94 \\
& Ramnathpur & 12.56 & 16.87 \\
\hline S.E. ( \pm ) & & 0.74 & 0.77 \\
\hline \%CV & & 22.16 & 22.49 \\
\hline
\end{tabular}

It should be noted that crops grown using combined nutrients i.e. household waste and recommended $\mathrm{N}$ following IPNS concept were found somewhat better over solitary application of either organic or inorganic nutrients. The fresh yield of Palong shak was found $16 \mathrm{t} \mathrm{ha}^{-1}$ when recommended doses of inorganic fertilizers were applied, but it was about 19 t ha- $^{-1}$ under combined application of organic and inorganic nutrients in both years.

Fresh yields of Lal shak and Pui shak were significantly influenced by different nutrient levels over the control, but location did not show any significant effect on its yield in Kawnia and Badarganj (Table 9 and 10). Yields of Lal shak grown using combined nutrients i.e. household waste and recommended $\mathrm{N}$ following IPNS concept were found significantly higher over recommended doses of fertilizers and only household waste. In case of Pui shak, application of recommended fertilizers and only household waste provided same amount of yield i.e. $45 \mathrm{t} \mathrm{ha}^{-1}$, however combined applications of inorganic fertilizers and household waste gave significantly higher yield over solitary application of either organic or inorganic fertilizer. The fresh yield of Pui shak was found about $49 \mathrm{t} \mathrm{ha}^{-1}$ under combined application of organic and inorganic nutriments.

Table 9. Fresh yield of Lal shak and Pui shak under different nutrient levels in Kawnia and Badarganj, Rangpur

\begin{tabular}{lcc}
\hline \multirow{2}{*}{ Nutrient levels } & \multicolumn{2}{c}{$\begin{array}{c}\text { Fresh yield of Lal shak } \\
\text { and Pui shak ( } \text { t ha-1 }^{-1}\end{array}$} \\
\cline { 2 - 3 } & Lal shak & Pui shak \\
\hline Control & $9.91 \mathrm{~d}$ & $16.72 \mathrm{c}$ \\
Recommended doses of NPK & $20.61 \mathrm{c}$ & $45.19 \mathrm{~b}$ \\
Household waste 10 t ha $^{-1}$ & $29.07 \mathrm{~b}$ & $45.36 \mathrm{~b}$ \\
Household waste 10 t ha $^{-1}+$ & $34.79 \mathrm{a}$ & $48.66 \mathrm{a}$ \\
RD of N (IPNS concept) & & \\
\hline S.E. $( \pm)$ & 0.65 & 1.13 \\
\hline \%CV & 17.51 & 18.41 \\
\hline
\end{tabular}

Table 10. Fresh yield of Lal shak and Pui shak under different locations in Kawnia and Badarganj, Rangpur

\begin{tabular}{llcc}
\hline \multirow{2}{*}{ Locations } & & \multicolumn{2}{c}{$\begin{array}{c}\text { Fresh yield of Lal shak } \\
\text { and Pui shak }\left(\mathrm{t} \mathrm{ha}^{-1}\right)\end{array}$} \\
\hline Upazila & Village & Lal shak & Pui shak \\
\hline Kawnia & Kachu & 22.75 & 39.34 \\
& Shingerkura & 23.22 & 37.42 \\
& Nazirdah & 25.11 & 39.80 \\
& Shabdi & 24.34 & 42.52 \\
& Haragach & 22.69 & 37.41 \\
& Amrulbari & 21.08 & 40.40 \\
Badarganj & Nataram & 23.59 & 39.31 \\
& Rajarampur & 23.42 & 35.56 \\
& Gopalpur & 24.84 & 38.78 \\
& Ramnathpur & 24.93 & 39.29 \\
\hline S.E. $( \pm)$ & & 1.03 & 1.79 \\
\hline \%CV & & 17.51 & 18.41 \\
\hline
\end{tabular}


Treatments containing different levels of nutrients significantly improved soil $\mathrm{pH}$ and $\mathrm{OM}$ in soils after harvesting of Lal shak in Kawnia and Badargonj, Rangpur (Table 11). Though the treatments did not show any significant effects on $\mathrm{N}, \mathrm{P}$ and $\mathrm{K}$ contents in soils after harvesting of the crop, however these parameters were improved in soils with the application of household waste. The increment of nutrients in soils with the application of household waste compost indicated the improvement of soil fertility. Different locations did not show significant effect on residual nutrients in soils after harvesting of Lal shak (Table 12).

Table 11. Soil properties after harvesting of Lal shak under different nutrient levels in Kawnia and Badarganj, Rangpur

\begin{tabular}{lccccc}
\hline \multirow{2}{*}{ Nutrient levels } & \multicolumn{5}{c}{ Soil properties at crop harvest } \\
\cline { 2 - 6 } Control & $\mathrm{pH}$ & $\mathrm{OM}(\%)$ & $\mathrm{N}(\%)$ & $\mathrm{P}\left(\mathrm{mg} \mathrm{kg}^{-1}\right)$ & $\mathrm{K}\left(\mathrm{meq}^{\left.100 \mathrm{~g}^{-1}\right)}\right.$ \\
Recommended doses of NPK & $5.15 \mathrm{~b}$ & $1.13 \mathrm{~b}$ & 0.10 & 14.12 & 0.17 \\
Household waste 10 $\mathrm{t} \mathrm{ha}^{-1}$ & $5.18 \mathrm{~b}$ & $1.14 \mathrm{a}$ & 0.13 & 15.23 & 0.23 \\
Household waste 10 $\mathrm{t} \mathrm{ha}^{-1}+\mathrm{RD}$ of N (IPNS concept) & $5.85 \mathrm{a}$ & $1.30 \mathrm{a}$ & 0.12 & 18.54 & 0.23 \\
\hline S.E. $( \pm)$ & 0.11 & $1.35 \mathrm{a}$ & 0.14 & 17.09 & 0.25 \\
\hline \%CV & 12.61 & 19.04 & 0.004 & 0.44 & 0.01 \\
\hline
\end{tabular}

Table 12. Soil properties after harvesting of Lal shak under different locations in Kawnia and Badarganj, Rangpur

\begin{tabular}{lllr}
\hline Locations & & & \\
\hline Upazila & Village & $\mathrm{pH}$ & OM \\
\hline \multirow{4}{*}{ Kawnia } & Kachu & 5.51 & 1 \\
& Shingerkura & 5.75 & 1.2 \\
& Nazirdah & 5.29 & 1.6 \\
& Shabdi & 5.61 & 1.28 \\
Badarganj & Haragach & 5.51 & 1.37 \\
& Amrulbari & 5.52 & 1.5 \\
& Nataram & 5.70 & 1.2 \\
& Rajarampur & 5.41 & 1 \\
& Gopalpur & 5.67 & 1 \\
& Ramnathpur & 5.53 & 1 \\
S.E. $( \pm)$ & & 0.17 & 0.0 \\
\hline \%CV & & 12.61 & 19.2 \\
\hline
\end{tabular}

Yields of lal shak, pui shak and tomato

Yields of Lal shak, Pui shak and Tomato were significantly affected by different nutrient levels over the control (Table 13). However, yield of Lal shak and Pui shak among recommended doses of chemical fertilizers, household waste compost alone and combined application of household waste and chemical fertilizer was statistically similar. Tomato yield was higher in household waste compost alone and combined application of household waste and chemical fertilizer over recommended doses of chemical fertilizers. From the results, it was observed that combined application of nutrients using organic and inorganic sources performed better.

Table 13. Fresh yield of Lal shak, Pui shak and Tomato under different nutrient levels in Kawnia, Rangpur

\begin{tabular}{|c|c|c|}
\hline Nutrient levels & $\begin{array}{l}\text { Yield of Yield of } \\
\text { lal shak pui shak } \\
\left(\mathrm{t} \mathrm{ha}^{-1}\right)\left(\mathrm{t} \mathrm{ha}^{-1}\right)\end{array}$ & $\begin{array}{l}\text { Tomato } \\
\text { fruit } \\
\text { yield } \\
\left(\mathrm{t} \mathrm{ha}^{-1}\right)\end{array}$ \\
\hline Control & 14.33b & $24.10 \mathrm{c}$ \\
\hline Recommended doses of NPK & 17.35a 30.80a & $63.70 \mathrm{~b}$ \\
\hline Household waste 10 t ha $^{-1}$ & $20.75 a 33.48 a$ & 78.67a \\
\hline $\begin{array}{l}\text { Household waste } 10 \mathrm{tha}^{-1}+ \\
\text { RD of N (IPNS concept) }\end{array}$ & $20.85 a 32.98 a$ & $75.35 a$ \\
\hline S.E. $( \pm)$ & 2.08 & 3.65 \\
\hline$\% \mathrm{CV}$ & 23.02 & 12.09 \\
\hline
\end{tabular}

\begin{tabular}{lccc}
\multicolumn{5}{c}{ Soil properties at crop harvest } \\
\hline M(\%) & $\mathrm{N}(\%)$ & $\mathrm{P}\left(\mathrm{mg} \mathrm{kg}^{-1}\right)$ & $\mathrm{K}\left(\mathrm{meq} 100 \mathrm{~g}^{-1}\right)$ \\
\hline 1.19 & 0.09 & 15.93 & 0.25 \\
1.20 & 0.10 & 17.07 & 0.22 \\
1.66 & 0.08 & 15.85 & 0.23 \\
1.28 & 0.11 & 16.20 & 0.20 \\
1.37 & 0.10 & 14.43 & 0.21 \\
1.50 & 0.12 & 16.38 & 0.23 \\
1.23 & 0.11 & 18.04 & 0.19 \\
1.19 & 0.13 & 14.32 & 0.22 \\
1.24 & 0.11 & 19.93 & 0.25 \\
1.18 & 0.15 & 16.85 & 0.20 \\
0.06 & 0.01 & 0.69 & 0.01 \\
9.20 & 30.40 & 17.23 & 14.37
\end{tabular}

Treatments containing different levels of nutrients did not show significant effects on soil $\mathrm{pH}$ and nutrients except potassium in soils after harvesting of tomato in Kawnia, Rangpur (Table 14). However, soil $\mathrm{pH}, \mathrm{OM}$, nitrogen and phosphorous were improved in soils with the application of household waste compost. Application of household waste compost alone and in combination with inorganic fertilizers increased soil $\mathrm{K}$ level over the control and recommended doses of chemical fertilizers. The increment of nutrients in soils with the application of household waste compost indicated the improvement of soil fertility.

Table 14. Soil properties after harvesting of Tomato under different nutrient levels in Kawnia, Rangpur

\begin{tabular}{|c|c|c|c|c|c|}
\hline \multirow[b]{2}{*}{ Nutrient levels } & \multicolumn{5}{|c|}{ Soil properties at crop harvest } \\
\hline & $\mathrm{pH}$ & OM & $\mathrm{N}$ & $\mathrm{P}(\mathrm{mg}$ & K(meq \\
\hline Control & 5.56 & 1.22 & 0.08 & 10.01 & $0.12 \mathrm{~b}$ \\
\hline $\begin{array}{l}\text { Recommended } \\
\text { doses of NPK }\end{array}$ & 5.58 & 1.21 & 0.09 & 10.22 & $0.13 \mathrm{~b}$ \\
\hline $\begin{array}{l}\text { Household waste } \\
10 \mathrm{t} \mathrm{ha}^{-1}\end{array}$ & 5.71 & 1.29 & 0.11 & 11.31 & $0.20 a$ \\
\hline $\begin{array}{l}\text { Household waste } \\
10 \text { t ha- }^{-1}+\text { RD of } \\
\text { N (IPNS concept) }\end{array}$ & 5.63 & 1.27 & 0.11 & 12.11 & $0.22 \mathrm{a}$ \\
\hline S.E. $( \pm)$ & 0.15 & 0.08 & 0.006 & 0.52 & 0.02 \\
\hline$\% C V$ & 11.55 & 15.32 & 27.38 & 14.89 & 19.56 \\
\hline
\end{tabular}




\section{Case study}

Punil Chandra Roy, a medium farmer of the Rajarampur village of Badarganj upazila was selected as a participatory farmer of the project. Mr. Roy actively participated in the project training, positively motivated and gave consent to work to achieve the project mission. He dug a pit in front of his house and started collecting and piling all his decomposable household wastes therein. As per instruction, he covered the pit with a thin layer of soil when sufficient household wastes were collected in the pit. Mr. Roy observed the decomposition of the household wastes into compost. After three months, the household wastes decomposed into household wastes compost which was $26 \mathrm{~kg}$ in weight. Mr. Roy prepared a land of 4 decimal subdivided into 8 plots using household wastes compost at different doses. He grew Palong shak in the plots and got the differences of using household wastes compost within a very short time. He found the plots with only household wastes composts (@ 10 t ha-1) showed better result. Second time he continued it with Pui shak without any chemical fertilizers. Third time he produced Lal shak using only household wastes compost and got the similar result. Neighbors visited his household wastes pit and vegetables plots. They became interested to hear from him and motivated to do the same in their homestead. Mr. Khokon Chandra Roy, one of the sons of Mr. Punil Chandra Roy, took the leadership of convincing people in preparation and use of household wastes compost for vegetable production. Like Mr. Roy, other participating farmers also got benefit from this project and committed to continue it with increasing rate along with their neighboring farmers. The main outcome of the project is successful preparation of household wastes compost and better performance of household wastes compost in vegetable production. Rural household dwellers can have vegetable production without using chemical fertilizers, which is economic for the rural poor. It will also increase the soil health with added organic matter in the soil and will maintain sound environmental condition. The policy makers may include this idea during formulation of environmentally sound and economically viable vegetable production in the homestead.

\section{Conclusion}

Most of the farmers under study showed low-level knowledge on household compost preparation as well as benefits of vegetable cultivation. Household waste compost has all the potentials to be used as a soil amendment, improving soil fertility and crop productivity and farmers have been motivated to prepare and use household waste compost for vegetable production in their homestead. Application of household waste compost @ 10t ha-1 along with inorganic fertilizers as IPNS based was found the best for short duration vegetables like Lal shak, Palong shak, Pui shak and also Tomato production over the sole application of either household waste compost or recommended doses of inorganic fertilizers. Household waste is available in the rural areas. Its compost is well proved as economic and valued source of plant nutrients to be applied to soils for crop production. Once household waste compost is applied @ $10 \mathrm{t} \mathrm{ha}^{-1}$ along with inorganic fertilizers as IPNS based, cultivation of three successive short duration vegetables is recommended for farmers' practice without applying any organic or inorganic fertilizers. Policy makers may take into consideration to circulate the technology to the rural household dwellers through extension organization.

\section{References}

BARC. 2005. Fertilizer recommendation guide, Bangladesh Agricultural Research Council (BARC). Soil publication No. 45. Farm Gate, Dhaka 1215, Bangladesh. 260p.

Barker, D.E. and Surh, N.H. 1982. Atomic absorption and flame emission spectroscopy. In: Page AL, Miller RH, Keeny DR (ed.) Methods of soil analysis, Part 2, Chemical and microbiological properties. American Society of Agronomy and Soil Science Society of America, Inc., Madison, Wisconsin, USA. pp. 13-26.

Bremner, J.M. and Mulvaney, C.S. 1982. Total nitrogen. In: Page, A.L., R.H. Miller and D.R. Keeny (ed.). Methods of soil analysis, Part 2, Chemical and microbiological properties, $2^{\text {nd }}$ edition. American Society of Agronomy and Soil Science Society of America, Inc., Madison, Wisconsin, USA. pp. 595-624.

Jones Jr, J.B. and Case, V.W. 1990. Sampling, handling and analyzing plant tissue samples. In: Westermaan WS (ed.). Soil testing and plant analysis, $3^{\text {rd }}$ edition, SSSA Book series 3, Soil Science Society of America, Madison, WI, USA. pp. 389-427.

Karim, Z., Miha, M.M.U. and Razia, S. 1994. Fertilizer in the national economy and sustainable environmental development. Asia Pacific J. Envir. Div. 1: 48-67.

Keeney, D.R. and Nelson, D.W. 1982. Nitrogeninorganic forms. In: Page, A.L., R.H. Miller and D.R. Keeny (ed.). Methods of soil analysis, Part 2, Chemical and microbiological properties. American Society of Agronomy and Soil Science Society of America, Inc., Madison, Wisconsin, USA. pp. 643-698. 
McLean, E.O. 1982. Soil pH and lime requirement. In: Page, A.L., R.H. Miller and D.R. Keeny (ed.). Methods of soil analysis, Part 2, Chemical and microbiological properties. American Society of Agronomy and Soil Science Society of America, Inc., Madison, Wisconsin, USA. pp. 199-224.

Nelson, D.W. and Sommers, L.E. 1982. Total carbon, organic carbon, and organic matter. In: Page, A.L., R.H. Miller and D.R. Keeny (ed.). Methods of soil analysis, Part 2, Chemical and microbiological properties. American Society of Agronomy and Soil Science Society of America, Inc., Madison, Wisconsin, USA. pp. 539-579.

Olsen, S.R. and Sommers, L.E. 1982. Phosphorus. In: Page, A.L., R.H. Miller and D.R. Keeny (ed.). Methods of soil analysis, Part 2, Chemical and microbiological properties.
American Society of Agronomy and Soil Science Society of America, Inc., Madison, Wisconsin, USA. pp. 403-430.

Rahman, M.M. 2010. Effect of different organic wastes in tomato (Lycopersicon esculentum Mill.) cultivation. J. Env. Sci \& Nat. Res. 3 (1): 247-251.

Rahman, M.M. and Azam, G.M. 2005. Fertility evaluation of Old Meghna River Floodplain soils in Bangladesh for sustainable agriculture. Chiang Mai J. Sci. 32 (2): 127137.

Watson, M.E. and Isaac, R.A. 1990. Analytical instruments for soil and plant analysis. In: Westermaan WL (ed). Soil testing and plant analysis, $3^{\text {rd }}$ edition. SSSA Book series 3, Soil Science Society of America, Madison, WI, USA. pp. 691-740. 